\section{Functional Differences In Gingival Fibroblasts Obtained from Young and Elderly Individuals}

Taisa Nogueira Pansani' , Fernanda Gonçalves Basso², Diana Gabriela Soares' Josimeri Hebling ${ }^{2}$, Carlos Alberto de Souza Costa ${ }^{3}$
'Department of Dental Materials and Prosthodontics, UNESP - Univ Estadual Paulista, Araraquara School of Dentistry, Araraquara, SP, Brazil ${ }^{2}$ Department of Orthodontics and Pediatric Dentistry, UNESP - Univ Estadual Paulista, Araraquara School of Dentistry, Araraquara, SP, Brazil ${ }^{3}$ Department of Physiology and Pathology, UNESP - Univ Estadual Paulista, Araraquara School of Dentistry, Araraquara, SP, Brazil

Correspondence: Carlos Alberto de Souza Costa, Rua Humaitá, 1680, Centro, 14801-903 Araraquara, SP, Brazil. Tel: +55-16-3301-6477. E-mail: casouzac@foar.unesp.br well as the synthesis of factors growth and extracellular matrix molecules. However, cell aging and the individual himself can lead to reduction of cell functions and consequently, the ability of tissue repair. This study evaluated the activity of gingival fibroblasts from young $(Y)$ and elderly $(Y)$ patients and their responsiveness to tumor necrosis factor alpha (TNF- $\alpha$ ). Gingival fibroblasts were isolated from six patients (3Y; and $3 E$ ) and seeded in complete culture medium (DMEM). For cell viability analysis, total protein production and collagen synthesis, fibroblasts were cultured in 96-well plates for 24,48 or $72 \mathrm{~h}(\mathrm{n}=36)$. Cell responses to TNF- $\alpha$, was evaluated by application of this cytokine to cultured cells $(100 \mathrm{ng} / \mathrm{mL}$ ) for $24 \mathrm{~h}$, followed by evaluation of reactive oxygen species (ROS), nitric oxide (NO) and CCL5 production ( $n=36$ ). Data were analyzed by Kruskal-Wallis and the MannWhitney $U$ tests $(\alpha=0.05)$. Viability of $E$ fibroblasts was higher than $Y$ fibroblasts for 24 and $48 \mathrm{~h}$, but these cells showed gradual reduction of viability over the course of time. For $Y$ cells, reduced collagen synthesis was observed at $48 \mathrm{~h}$. No difference was observed in ROS production for both cells after TNF- $\alpha$ exposure. However, both cultures showed increased production of NO and CCL5 in the presence of TNF- $\alpha$. Functional differences and distinct responsiveness to TNF- $\alpha$ were observed according to patient's age.

\begin{abstract}
Key Words: cell aging, wound healing, tumor necrosis factor alpha
\end{abstract}

\section{Introduction}

Previous studies have shown that aging can cause morphological and functional cellular changes, such as reduction of proliferative capacity, number of organelles, growth factor expression and collagen synthesis, and that these changes can delay the repair process $(1,2)$. Fibroblasts actively participate in the tissue repair process by proliferating, migrating and filling the wound, beyond the synthesis of growth factors and extracellular matrix molecules (2). An effective tissue repair, especially in cases of surgical implants installation leads to an aesthetic and favors the longevity of the rehabilitation treatment (3). Therefore, diminished metabolism and proliferation of these cells could delay wound healing (4). Studies verified that gingival fibroblasts present an increased repair capacity compared with skin fibroblasts, due to the enhanced migration capability and rapid re-population of the wound. These cells also exhibit higher synthesis of growth factors and the deposition of a more organized and effective surrounding matrix $(3,5)$, supporting the rapid repair of the oral mucosa even around the dental implants.

Tissue repair process consists of essentially four phases, which may overlap: hemostasis, inflammation, proliferation and tissue remodeling $(1,5)$. The inflammatory phase, a direct consequence of the injury, plays an important role at the beginning of the healing process, aimed at morphological and functional recovery of the tissue (6). Additionally, this phase is essential for the elimination of bacteria and microbial contaminants that can delay the repair process. It has been demonstrated that bacteria and endotoxins can increase and prolong the production of pro-inflammatory cytokines such as interleukin 1 (IL-1ß) and tumor necrosis factor alpha (TNF- $\alpha$ ), thus extending the inflammatory phase (7). This, moreover, may also be related to the delay of tissue repair, due to a decreased proliferative capacity of the cells involved in this process (8) which affect negatively the aesthetic and function of osseointegrated oral implants. However, few studies have reported comparatively functional differences between gingival fibroblasts from young and elderly individuals and their responsiveness to inflammatory process $(9,10)$.

As individuals age, cells can exhibit a gradual loss of replicative potential and a lower response to growth factors, which can reduce tissue repair capacity (1). Previous studies have shown that, in elderly individuals, healing has become delayed, and for these individuals, inflammatory response was reduced due to T cell infiltration in the wound site, as well as to changes in chemokine production and the phagocytic capacity of macrophages (9). However, despite the different studies that have evaluated the idiosyncrasies of the repair process in elderly individuals, few researchers 
have analyzed the influence of the aging process on the functions of cells effectively involved in oral mucosal repair (2) that might also influence during the rehabilitation treatment using dental implants. Thus, there is only limited knowledge about the influence of aging on the oral mucosal repair capacity of elderly patients and the inflammatory responses of oral mucosal cells in these patients. The aim of this research was to evaluate the viability and the metabolism of gingival fibroblasts obtained from young and elderly individuals and the responses of these cells when exposed to TNF- $\alpha$.

\section{Material and Methods}

The project was initially approved by the Research Ethics Committee of the Araraquara School of Dentistry/UNESP, SP, Brazil (CAAE \# 13514813.6.0000.5416). All participants signed the Instrument of Consent.

Six primary cultures were obtained from gingival fragments collected during a tooth extraction procedure or implant placement in three young adults (from 18 to 24 years of age) and three elderly individuals (over 65 years of age). Exclusion criteria, the following factors were considered: presence of systemic diseases, medication use, smoking and periodontal disease, and this information was obtained through anamnesis and clinical assessment. For cell isolation, fragments were incubated in culture medium (DMEM, Dulbecco's Modified Eagle's Medium; Gibco, Carlsbad, CA, USA) containing type I collagenase (Worthington Biochemical Corp.; Lakewood, NJ, USA) and were maintained in an incubator at $37{ }^{\circ} \mathrm{C}$ in a $5 \%$ $\mathrm{CO}_{2}$ atmosphere (Isotemp; Fisher Scientific, Pittsburgh, $\mathrm{PA}$, USA) for $24 \mathrm{~h}$. After this period, the tissue fragments were transferred to a $15 \mathrm{~mL}$ Falcon tube and centrifuged for 2 min (4000 $\times g$ Centrifuge T; Fanem, Guarulhos, SP, Brazil). The cell pellet was re-suspended in DMEM ( $1 \mathrm{~mL})$ containing 10\% of fetal bovine serum (FBS - Gibco) and transferred to a cell culture flask of $75 \mathrm{~cm}^{2}$ to obtain the amount necessary for the experiment.

\section{Cell Culture}

The cells (5-8 passages) in the same passage were cultured in 96-well plates (TPP- Techno Plastic Products, Trasadingen, Switzerland) $\left(9 \times 10^{3} \mathrm{cells} / \mathrm{cm}^{2}\right)$ in complete DMEM (DMEM with $10 \%$ of fetal bovine serum). For each repetition, samples from 6 individuals were selected (3 young and 3 elderly) and 6 samples were seeded per patient (18 samples in Y group and 18 samples in E group), and this study was development in duplicate, totalized $n=36$ per group (young and elderly). After $24 \mathrm{~h}$, the culture medium was replaced by a fresh serum-free DMEM. For comparison of the functional activity of fibroblasts obtained from young and elderly individuals, a viability test (MTT Assay), total protein production (TP) and collagen synthesis (Sirius Red Assay) were performed after experimental incubation periods of 24,48 and $72 \mathrm{~h}$. For comparative evaluation, the responses of gingival fibroblasts obtained from young and elderly individuals, whether exposed or not to the inflammatory mediator, $100 \mathrm{ng} / \mathrm{mL}$ of TNF- $\alpha$ in serum-free DMEM, were maintained in contact with the cells for 24 $h$, based in a study that compared the dose-response by this inflammatory mediator (unpublished data). After this period, the production of reactive oxygen species (ROS) and nitric oxide (NO) and the synthesis of the chemokine CCL5 were evaluated.

\section{Cell Viability Evaluation (MTT Assay)}

Cell viability was determined by means of the methyl thiazolyl tetrazolium (MTT) colorimetric assay (12) This method determines the respiratory activity of the cell culture by cleavage of MT salt [3-(4,5-dimethyltriazol2YL) -2,5-diphenyl bromide tetrazolium (Sigma-Aldrich, St. Louis, MO, USA), by the succinate dehydrogenase enzyme system, resulting in soluble crystals (formazan crystals).

On the cells cultivated in 96-well plates, $90 \mu \mathrm{L}$ of culture medium (DMEM) without FBS and $10 \mu \mathrm{L}$ of MTT solution (5 $\mathrm{mg} / \mathrm{mL}$ in PBS) were added to the samples. The cells remained in contact with the MTT solution in a $\mathrm{CO}_{2}$ incubator at $37^{\circ} \mathrm{C}$ for $4 \mathrm{~h}$, when the formation of formazan crystals was observed. After this period, the MTT solution was aspirated and replaced with $100 \mu \mathrm{L}$ of acidified isopropanol solution $(0.04 \mathrm{~N}$ of $\mathrm{HCl})$, for solubilization of the crystals, generating a homogeneous solution which was subjected to absorbance analysis in a spectrophotometer (Synergy H1; BioTek, Winooski, VT, USA) at a wavelength of $570 \mathrm{~nm}$. Absorbance expressed in numerical values was transformed into percentage according to the cell groups of the young individuals, over a $24 \mathrm{~h}$ period, and subjected to statistical analysis (11).

\section{Total Protein Production}

Total protein production analysis was performed by the Lowry method. The culture medium was aspirated, and $100 \mu \mathrm{L}$ of $0.1 \%$ sodium lauryl sulphate solution (SigmaAldrich) were added to each sample, which remained under incubation for $40 \mathrm{~min}$ at room temperature to promote cell lysis. After this, $100 \mu \mathrm{L}$ of Lowry reagent (Sigma-Aldrich) were added to each sample for a period of $20 \mathrm{~min}$. Finally, $50 \mu \mathrm{L}$ Folin-Ciocalteu's Reagent (Sigma-Aldrich) were added and maintained for $30 \mathrm{~min}$ for absorbance readout in a spectrophotometer (Synergy H1; BioTek) at $665 \mathrm{~nm}$ (11). Total protein production was determined relative to the percentage of the group of young individuals in the $24 \mathrm{~h}$ period. 


\section{Collagen Synthesis (Sirius Red Assay)}

The concentration of collagen synthetized by the cultured gingival fibroblasts was determined by the Sirius Red assay. This method is based on the selective binding of the Direct Red dye (Sigma-Aldrich), in a saturated solution of picric acid, to the collagen fiber types I to IV, identifying and quantifying the total soluble collagen present in the sample.

For this assay to be performed, the culture medium was collected and stored at $-20^{\circ} \mathrm{C}$ until the test was performed. To the $200 \mu \mathrm{L}$ of culture medium collected and $200 \mu \mathrm{L}$ of the Direct Red solution (0.5 M in picric acid) were added, followed by incubation under agitation for $60 \mathrm{~min}(400$ rpm, room temperature) in a shaker (Thermomixer-Confort; Eppendorf, Hamburg, Germany). Next, this solution was centrifuged in a cooled microcentrifuge (Eppendorf $5415 \mathrm{R})$ at $12,000 \mathrm{rcf}$ for $10 \mathrm{~min}$. The supernatant was discarded, and $300 \mu \mathrm{L}$ of HCL $0.1 \mathrm{M}$ were added, followed by centrifugation at $12,000 \mathrm{rcf}$ for $10 \mathrm{~min}$. The supernatant was discarded one more time, and $250 \mu \mathrm{L}$ of $\mathrm{NaOH} 0.5$ $\mathrm{M}$ were added for homogenization of the samples under vigorous agitation. Aliquots of $100 \mu \mathrm{L}$, in duplicate, of the solution were transferred to 96 -well plates, and absorbance analysis was performed at a wavelength of $555 \mathrm{~nm}$ in a spectrophotometer (Synergy H1; BioTek). The concentration of total collagen was evaluated relative to the percentage of the group of young individuals in the $24 \mathrm{~h}$ period.

\section{Production of Reactive Oxygen Species (ROS)}

Increased production of reactive oxygen species is directly related to oxidative stress, which can result in molecule and organelle peroxidation and lead to irreversible damage. To determine ROS production by gingival fibroblasts obtained from young and elderly patients, a fluorescent probe (H2DCFDA; Invitrogen) was used. This probe is permeable to the cell membrane and allowed for the detection of these intracellular ROS, capable of binding these molecules permanently. The probe was added to the culture medium previous to the application of TNF- $\alpha$ and was maintained for $24 \mathrm{~h}$ in association with treatment, to allow for the immediate identification of ROS, as these molecules are highly reactive and unstable. After $24 \mathrm{~h}$, the culture medium was aspirated, and $500 \mu \mathrm{L}$ of PBS were added to each sample. The amount of ROS was determined by the fluorescence intensity of the probe in each sample when each compartment was scanned (excitation, $488 \mathrm{~nm}$; emission, $540 \mathrm{~nm}$ ) by a fluorimeter (Synergy H1; BioTek).

\section{Nitric Oxide Production (NO)}

Nitric oxide is also an important mediator in cellular inflammatory and tissue responses and, in low concentrations, is also capable of promoting cell proliferation. In high concentrations, NO can cause severe tissue damage (12). The quantification of NO produced by cells in culture was determined by detection of nitrite accumulation in the cell culture supernatant by the diazotisation reaction with Griess reagent (Sigma-Aldrich).

A $50 \mu \mathrm{L}$ aliquot of the culture medium maintained in contact with the cells for the proposed treatment was transferred to another 96-well plate, and Griess reagent was added in the same proportion. After 10 min incubation at ambient temperature in the absence of light, the concentration of $\mathrm{NO}$ was determined by the absorbance of the solution determined at $540 \mathrm{~nm}$ in a spectrophotometer (Synergy H1; BioTek).

\section{CCL5 Chemokine Expression}

The CCL5 chemokine is highly expressed during the inflammatory process and is associated with the migration of other inflammatory cells (13). Evaluation of the expression of this chemokine was performed by ELISA immunoassay (enzyme-linked immunosorbent assay), based on an antigen-antibody reaction, which was performed according to manufacturer's recommendations (RED Systems, Minneapolis, MN, USA). Thus, the culture medium in contact with the cells was collected and stored at -20 ${ }^{\circ} \mathrm{C}$ until being tested.

For the ELISA assay, 96-well plates were treated with specific primary antibodies $(2 \mu \mathrm{g} / \mathrm{mL})$ and incubated overnight. Washes were then performed $(2.5 \%$ wash solution), followed by incubation with blocking solution ( $1 \% \mathrm{BSA})$ for $1 \mathrm{~h}$ at room temperature. After being washed, $100 \mu \mathrm{L}$ of each sample and standard curve concentrations were added, and the plates were incubated for $2 \mathrm{~h}$ at room temperature, followed by further washing. Next, the secondary antibody was added $(400 \mathrm{ng} / \mathrm{mL})$ and incubated for an additional $2 \mathrm{~h}$. Samples were washed, and streptavidin $(1: 400)$ was added for $20 \mathrm{~min}$ in the dark. New washes were performed, and the substrate solution was added and maintained for $20 \mathrm{~min}$. Finally, Stop solution was added to stop the reaction, and the optical density of the obtained samples was measured by spectrophotometry (Synergy H1; BioTek) at a $450 \mathrm{~nm}$ wavelength. The CCL5 concentrations were determined according to the standard curve.

\section{Cell Morphology (Phase Contrast Microscopy)}

Images of fibroblastic cells from young and elderly individuals were obtained using a phase contrast microscope in 4x magnification (TS 100 Nikon, Tokyo, Japan) equipped with digital image acquisition system. The periods of evaluation were 24,48 and $72 \mathrm{~h}$ of cell culture.

\section{Statistical Analysis}

Due to non-adherence of data to the normal curve, 
the non-parametric Kruskal-Wallis test, complemented by the Mann-Whitney U test, was applied, at a significance level of $5 \%$.

\section{Results}

For cells from young gingival tissue $(\mathrm{Y})$, no statistically significant difference was observed for the different time intervals evaluated. However, for elderly individuals cells $(E)$, a gradual reduction in cell viability was observed over the course of the incubation periods $(p<0.05)$. When the groups of $Y$ and $E$ individuals were compared, for each study period, there was increased cell viability in the $E$ individuals group at 24 and $48 \mathrm{~h}$, whereas the reverse was observed within $72 \mathrm{~h}(\mathrm{p}<0.05)$ (Fig. 1A).

Gingival fibroblasts from the E individuals group showed higher total protein production at $24 \mathrm{~h}(\mathrm{p}<0.05)$. When the groups of $E$ and $Y$ individuals' cells were compared within each period, the total protein production was higher only in the $24 \mathrm{~h}$ period for E cells (Fig. 1B).

No statistically significant difference in the collagen synthesis by the $Y$ group cells was observed, independent of the period $(p>0.05)$. For $E$ individuals' cells, reduced synthesis was observed at $48 \mathrm{~h}$, also presenting lower collagen production for the same period $(p<0.05)$ (Fig. 1C).

The ROS production by $Y$ individuals' fibroblasts did not differ statistically significantly from that observed for E individuals' cells when exposed to TNF- $\alpha$ (Fig. 2).

However, NO production was increased when the cells were in contact with TNF- $\alpha$, independently of the ages of patients $(p<0.05)$ (Fig. 3).

For the CCL5 synthesis expression, there was a statistically significant difference between the cells obtained from $Y$ and $E$ individuals' groups exposed to TNF- $\alpha$ (Fig. 4).

Images of $Y$ and $E$ fibroblasts under phase contrast microscope (TS 100, Nikon, Tokyo, Japan) at 24, 48 and $72 \mathrm{~h}$ of culture showed that those cells exhibited similar morphology. However, for E group it seems that a lower number of fibroblasts was present on the substrate when compared to Y group (Fig. 5).

\section{Discussion}

Aging is a gradual and continuous process involving numerous cellular and tissue changes on morphological, structural and functional levels (14). Previous studies showed that during the aging process there is a decrease in the proliferative capacity of cells, which also present lower protein metabolism and gene flow (14). However, the influence of the individual's aging on oral mucosal cell metabolism, such as gingival fibroblasts, has not been completely elucidated. Unlike most studies found in the literature, (2) in which cellular senescence was promoted
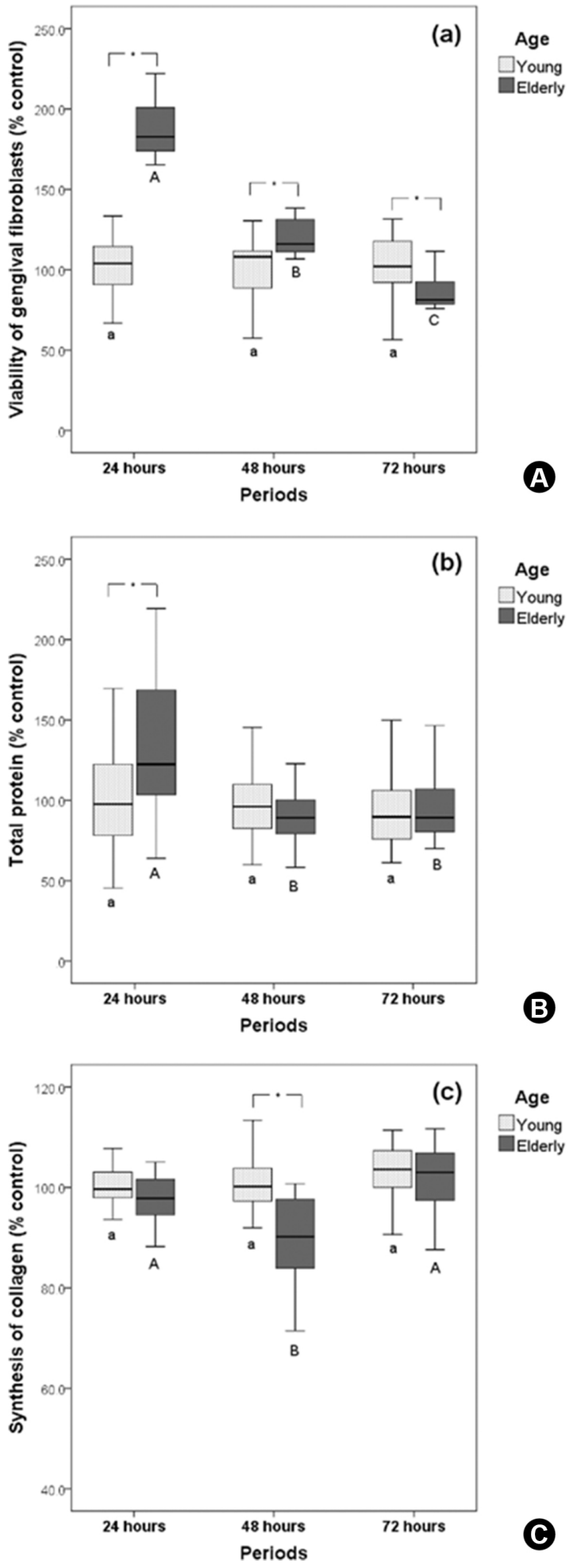

Figure 1. Cell viability (A), total protein production (B) and collagen synthesis (C) by fibroblasts obtained from the gingival tissue of healthy young and elderly individuals, evaluated after time intervals of 24,48 or $72 \mathrm{~h}$ of incubation. Letters allow comparisons among the time intervals of analysis for each age, while the asterisks allow comparisons between the ages for each time interval. Groups identified with different letters differed statistically, and so did groups indicated with asterisks. Values indicate median (25th-75th percentile), $n=36$ (Mann-Whitney, $\mathrm{p}<0.05$ ). Gradual reduction in cell viability over time incubation for E group was observed. E group showed higher total protein production at $24 \mathrm{~h}$. At $48 \mathrm{~h}$, collagen synthesis was reduced for E group. 
by increasing in vitro cell subculture, it was evaluated in the present investigation the influence of aging on gingival fibroblasts by isolating primary cultures of oral mucosa fibroblasts obtained from young and elderly individuals. In this study, the authors also assessed the possible discrepancy in the response of these oral mucosa cells exposed to tumor necrosis factor (TNF- $\alpha$ ) inflammatory cytokine. Therefore, since different behavior of young and elderly cells obtained from health individuals has been poorly presented in the literature, mainly under the data of this study certainly contribute with the research field.

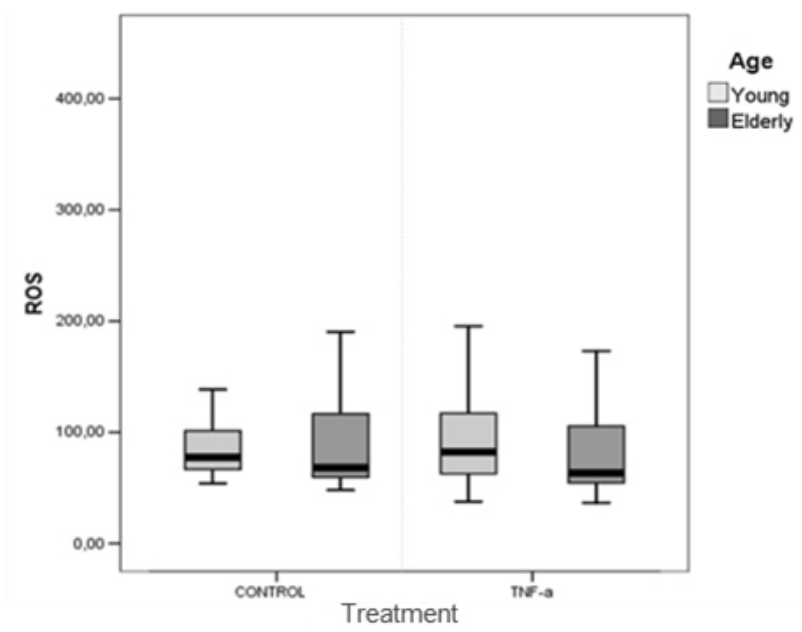

Figure 2. Reactive Oxygen Species (\% young control) by gingival fibroblasts compared at different ages (young and elderly) with or without TNF- $\alpha$. Values indicate median (25th-75th percentile), $n=$ 36. Mann-Whitney $(\mathrm{p}<0.05)$. No statistically significant difference in ROS production by $\mathrm{Y}$ and $\mathrm{E}$ groups.

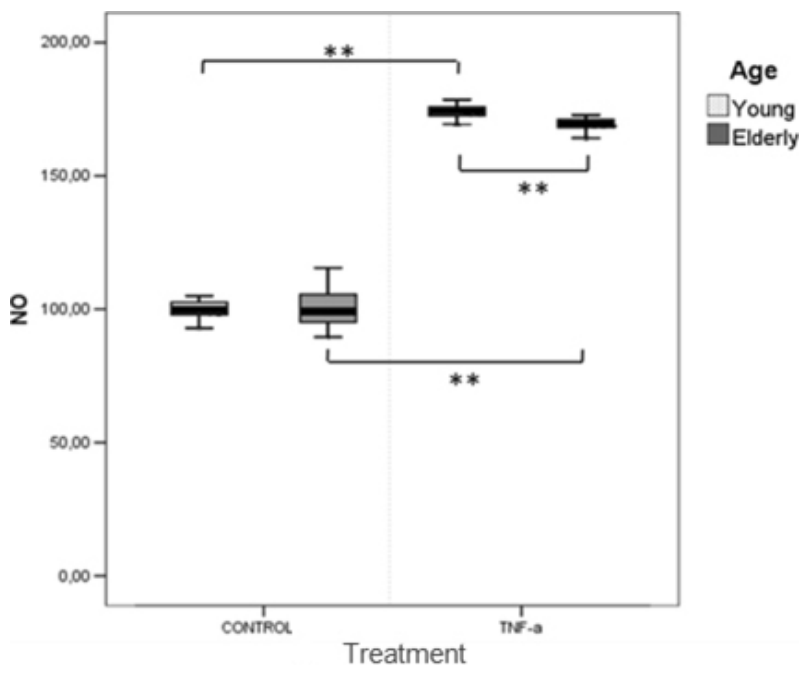

Figure 3. Nitric oxide (\% young control) by gingival fibroblasts compared at different ages (young and elderly) with or without TNF- $\alpha$. Values indicate median (25th-75th percentile), $\mathrm{n}=36$. Mann-Whitney $(p<0.05) .{ }^{* *} p<0.001$. NO production was increased with TNF- $\alpha$ stimuli for $\mathrm{Y}$ and $\mathrm{E}$ groups.
In the present study, it was observed that viability, total protein synthesis and collagen production by $Y$ gingival fibroblasts were not significantly affected by the time in culture $(24,48$ and $72 \mathrm{~h})$, whilst for cells obtained from $\mathrm{E}$ individuals, there was a time-dependent reduction in cell viability (Fig. 1). However, greater viability occurred when E individuals' cells were compared to the $Y$ individuals' fibroblasts at 24 and $48 \mathrm{~h}$. These data, obtained in initial periods, can be related to the premature adhesion of senescent cells, (2) which may allow E individuals' cells to start the mitosis process more quickly. Some studies have demonstrated changes in collagen production by cells from E individuals. Cultured late-passages fibroblasts also showed significant increased production of collagenases when compared to homologous early passages, (15) which can induce a degradation of soluble collagen synthetized by the cells, as observed in this study in E individuals' cells at $48 \mathrm{~h}$.

The repair process of oral mucosal injury is also dependent on other factors, such as inflammatory mediators (16). The presence of inflammation in tissues with high concentrations of chemokines and inflammatory mediators induces the generation of reactive oxygen species (ROS) by various cells $(17,18)$. At low concentrations, ROS can accelerate the repair process; however, at higher concentrations or prolonged exposure, ROS can cause tissue damage by lipid peroxidation in different organelles, such as the cell membranes (17). TNF- $\alpha$ is a pro-inflammatory cytokine, secreted from macrophages and other cells that participate in the inflammatory phase during the repair process. Low concentration of this cytokine in tissues is capable of stimulating repair by

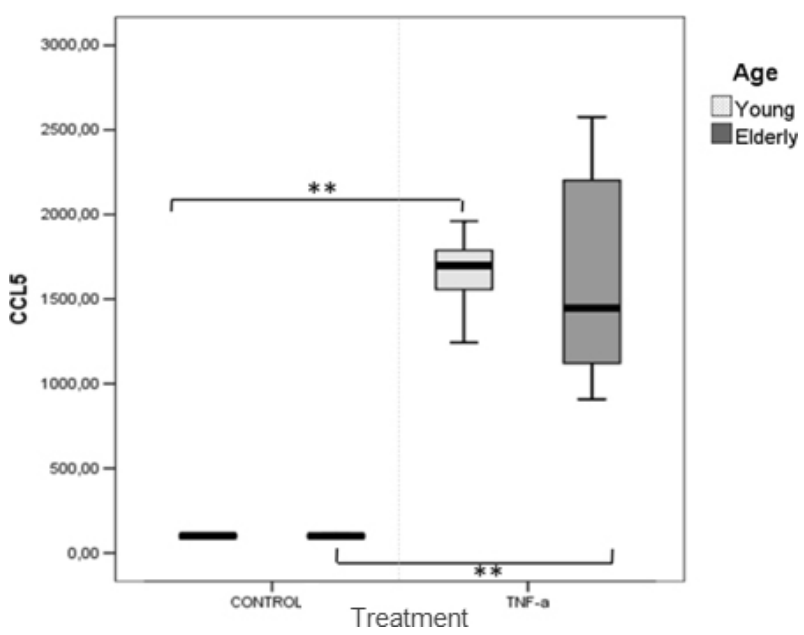

Figure 4. Synthesis of CCL5 (\% young control) by gingival fibroblasts compared at different ages (young and elderly) with or without TNF- $\alpha$ Values indicate median (25th-75th percentile), $\mathrm{n}=36$. MannWhitney $(\mathrm{p}<0.05),{ }^{* *} \mathrm{p}<0.001$. Higher concentration of CCL5 from $\mathrm{Y}$ and $\mathrm{E}$ cells expose to TNF- $\alpha$. 
activating macrophages and stimulating the production of growth factors. Conversely, at high concentrations or when it remains for extended periods in damaged tissue, this cytokine can hinder the local repair by increasing the synthesis of metalloproteinases and inhibiting the synthesis of extracellular matrix molecules and if inflammation of the peri-implant tissues remains, there could be gingival resection and even implant loss (19). In the present study, the authors selected TNF- $\alpha$ to simulate, in a limited way and in in vitro conditions, the activity of fibroblasts in inflamed tissue. Thus, it was possible to demonstrate that the production of ROS by cells exposed to TNF- $\alpha$ contact did not increase in both patient groups. TNF-induced ROS production via $\mathrm{p} 38$, JNK, and NF-kB by positive feedback loop and the innate response was TNF-mediated by ROS regulation (20). Additionally, the activation of NFkB pathway, can stimulate proinflammatory cytokine production by ROS (21). However, significant differences in NO production by gingival fibroblasts from $\mathrm{Y}$ and $\mathrm{E}$ patients were observed. This inflammatory mediator shows several physiological functions, including bactericidal properties. However, as for ROS, NO in high concentrations can promote cytotoxic effects and tissue damage particularly in inflamed tissues, such as in case of periodontitis and peri-implantitis (22).

The data obtained in this study were corroborated by Chung et al (18), who also demonstrated increased synthesis of NO related to inflammatory responses against cell aging. These authors reported that the largest increase in activation of the NFkB pathway also promoted a rise in some inflammatory cytokine synthesis, such as TNF- $\alpha$, interleukin 1 beta (IL-1 $\beta$ ), interleukin 6 (IL-6) and cyclooxygenase-2 (COX-2), leading to inflammatory diseases in the elderly.

During the inflammatory process in oral mucosal tissues, high concentrations of the CCL5 chemokine are synthesized and expressed by T cells and fibroblasts (23). Previous studies showed that CCL5 actively participates in the repair process, inducing migration of different types of inflammatory cells, such as leukocytes, to the site of inflammation (23). However, the maintenance of the expression of this cytokine, with the consequent persistence of inflammation, can lead to chronic wounds and the potential loss of underlying bone (24), resulting in delayed healing. It was assessed in the present in vitro study the cellular response of oral fibroblasts from young and elderly individuals to stimuli that mimic the presence of tissue inflammation. Of course, the data obtained in this investigation cannot be extrapolated directly to clinical situations. However, the authors demonstrated a significant increase in CCL5 synthesis by $\mathrm{Y}$ and $\mathrm{E}$ gingival fibroblasts when they were maintained in contact with TNF- $\alpha$. This finding determined that the gingival fibroblasts present inflammatory responses and modulate the cell migration activation involved in tissue repair. However, although no
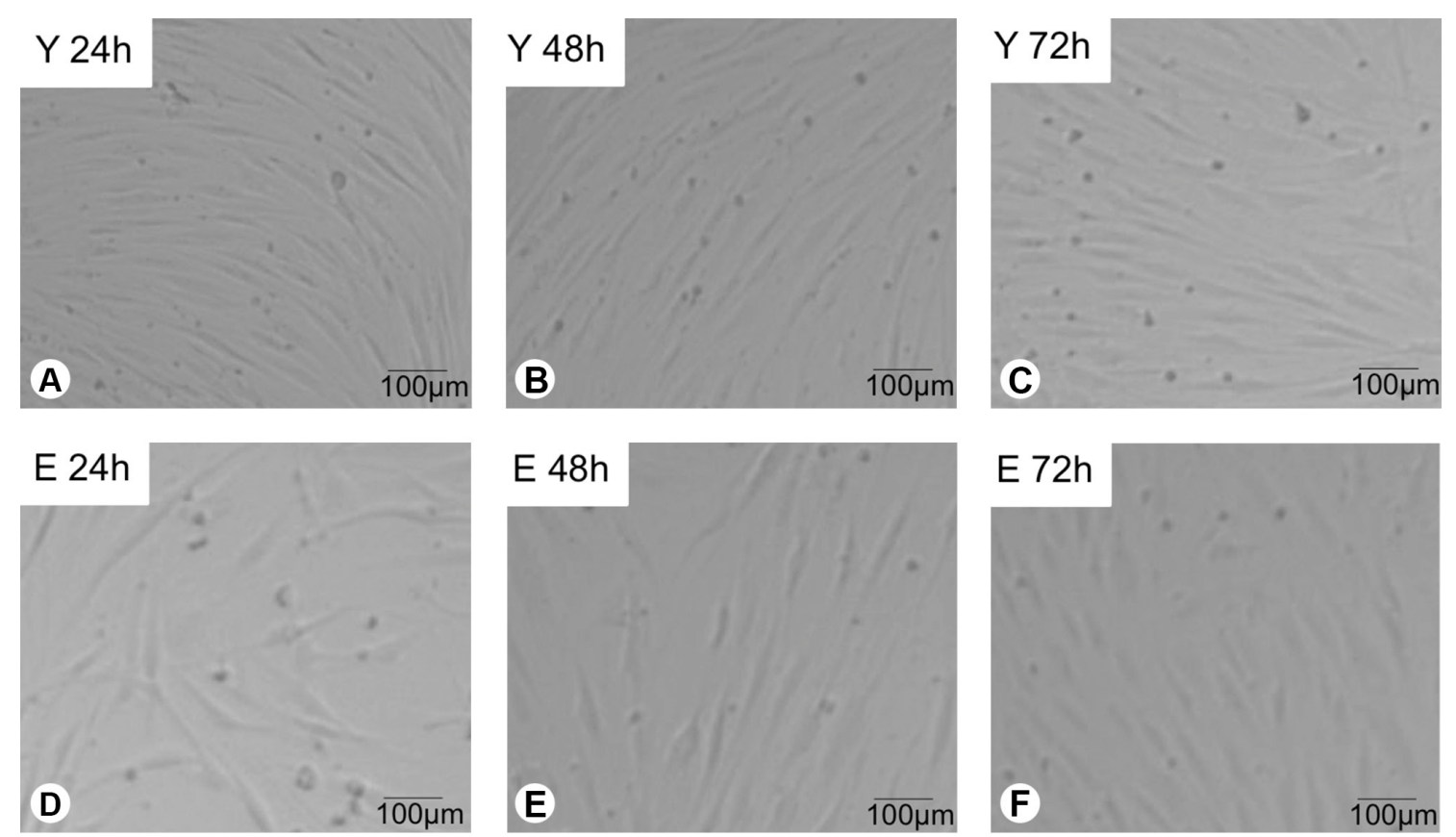

Figure 5. Cell imaging in phase contrast microscopy of fibroblastic cells. Y $24 \mathrm{~h}$ : Fibroblasts from young individuals at $24 \mathrm{~h}$ of culture; Y $48 \mathrm{~h}$ : Fibroblasts from young individuals at $48 \mathrm{~h}$ of culture; Y $72 \mathrm{~h}$ : Fibroblasts from young individuals at $72 \mathrm{~h}$ of culture; E $24 \mathrm{~h}$ : Fibroblasts from elderly individuals at $24 \mathrm{~h}$ of culture; E $48 \mathrm{~h}$ : Fibroblasts from elderly individuals at $48 \mathrm{~h}$ of culture; E $72 \mathrm{~h}$ : Fibroblasts from elderly individuals at $72 \mathrm{~h}$ of culture. 
statistically significant difference was observed for $\mathrm{Y}$ and E fibroblast groups, it was shown the increasing expression of CCL5 trends in E patients' cells, which can also lead to a delay in the repair process for these patients (24).

According to the methodology used in this in vitro study and considering the limitations of the laboratorial results presented, it can be stated that the fibroblasts functions discrepancies observed in cells obtained from young and elderly individuals, associated with the data previously described in the literature $(9,10,15)$, indicate a relationship between senescence and reduced repair capacity and even changes in the regulation of inflammatory cytokines (25) especially in periodontal tissues. Moreover, during the aging process the cells undergo phenotypic changes and respond differently, mainly towards molecules of the inflammatory process (18).

According to this study, patients' age is a factor that influences the activity of gingival fibroblasts. Thus, cell viability, total protein production and collagen synthesis by gingival fibroblasts were adversely affected by the increasing age of the individuals, with reduced cellular functions for cells obtained from elderly patients. However, patient age did not influence the responsiveness of these cells against the stimulation with TNF- $\alpha$, showing maintenance of the inflammatory response capability against pathogens.

\section{Resumo}

Fibroblastos participam no processo de reparação de ferida através da proliferação e migração, bem como a sintese de fatores de crescimento e moléculas da matriz extracelular. No entanto, o envelhecimento celular e o próprio indivíduo podem levar à redução de funções celulares $e_{\text {, }}$ consequentemente, a capacidade de reparação de tecidos. Este estudo avaliou a atividade dos fibroblastos gengivais de pacientes jovens (J) e idosos (I) e sua capacidade de resposta frente ao fator de necrose tumoral alfa (TNF- $\alpha$ ). Fibroblastos gengivais foram isolados de seis pacientes (3J e 3 l) e semeados em meio de cultura completo (DMEM). Para a análise de viabilidade celular, a produção de proteina total e a sintese de colágeno, fibroblastos foram cultivados em placas de 96 poços, durante 24,48 ou $72 \mathrm{~h}(\mathrm{n}=36)$. Respostas celulares frente ao TNF- $\alpha$, foram avaliadas por aplicação desta citocina (100 $\mathrm{ng} / \mathrm{mL}$ ) nas células cultivadas durante $24 \mathrm{~h}$, seguida por avaliação de espécies reativas de oxigênio (EROs), produção de óxido nitrico (NO) e produção CCL5 $(n=36)$. Os dados foram analisados por testes de Kruskal-Wallis e MannWhitney $\mathrm{U}(\alpha=0,05)$. A viabilidade de fibroblastos I foi mais elevada do que os fibroblastos J para 24 e $48 \mathrm{~h}$, mas estas células mostraram uma redução gradual de viabilidade ao longo do tempo. Para as células de J, foi observada redução da sintese de colágeno em $48 \mathrm{~h}$. Não foi observada diferença na produção de EROs para ambas as células após exposição ao TNF- $\alpha$. No entanto, ambas as culturas apresentaram aumento da produção de NO e CCL5 na presença de TNF- $\alpha$. Diferenças funcionais e alteração na capacidade de resposta ao TNF- $\alpha$ foram observadas de acordo com a idade do paciente.

\section{Acknowledgements}

The authors thank he São Paulo Research Support Foundation (FAPESP - grant 2015/19364-8) and the National Council for Scientific and Technological Development (CNPq - Grants 443153/2014-0, 303599/20146, 400984/2015-6, and 307696/2014-6) for financial support.

\section{References}

1. Gosain A, DiPietro LA. Aging and wound healing. World J Surg 2004;28:321-326.

2. Hwang ES, Gyesoon Y, Kang HT. A comparative analysis of the cell biology of senescence and aging. Cell Mol Life Sci 2009;66:2503-2524.

3. An N, Rausch-fan X, Wieland M, Matejka M, Andrukhov O, Schedle A. Initial attachment, subsequent cell proliferation/viability and gene expression of epithelial cells related to attachment and wound healing in response to different titanium surfaces. Dent Mater 2012;28:1207-1214.

4. Smith KC. Laser (and LED) therapy is phototherapy. Photomed Laser Surg 2005;23:78-80.

5. Enoch S, Peake MA, Wall I, Davies L, Farrier J, Giles P, et al.. 'Young' oral fibroblasts are geno/phenotypically distinct. J Dent Res 2010;89:14071413.

6. Li J, Chen J, Kirsner R. Pathophysiology of acute wound healing. Clin Dermatol 2007;25:9-18.

7. Guo S, DiPietro LA. Factors affecting wound healing. J Dent Res 2010;89:219-229.

8. Menke NB, Ward KR, Witten TM, Bonchev DG, Diegelmann RF. Impaired wound healing. Clin Dermatol 2007;25:19-25.

9. Swift ME, Burns $A L$, Gray KL, DiPietro LA. Age-related alterations in the inflammatory response to dermal injury. J Invest Dermatol 2001;117:1027-1035.

10. Cáceres $M$, Oyarzun $A$, Smith PC. Defective wound-healing in aging gingival tissue. J Dent Res 2014;93:691-697.

11. Basso FG, Pansani TN, Oliveira CF, Turrioni AP, Soares DG, Hebling J, et al.. Cytotoxic effects of zoledronic acid on human epithelial cells and gingival fibroblasts. Braz Dent J 2013;24:551-558.

12. Kendall HK, Marshall RI, Bartold PM. Nitric oxide and tissue destruction. Oral Dis 2001;7:2-10.

13. Deshmane SL, Kremlev S, Amini S, Sawaya BE. Monocyte chemoattractant protein-1 (MCP-1): an overview. J Interferon Cytokine Res 2009;29:313326.

14. Magalhães JP. From cells to ageing: a review of models and mechanisms of cellular senescence and their impact on human ageing. Exp Cell Res 2004;300:1-10.

15. Sottile J, Mann DM, Diemer V, Millis AJT. Regulation of collagenase and collagenase mRNA production in early- and late-passage human diploid fibroblasts. J Cell Physiol 1989;138:281-290.

16. Glim JE, Egmond M, Niessen FB, Everts V, Beelen RHJ. Detrimental dermal wound healing: What can we learn from the oral mucosa? Wound Rep Reg 2014;21:648-660.

17. Sculley DV, Langley-Evans SC. Salivary antioxidants and periodontal disease status. Proc Nutr Soc 2002;61:137-143.

18. Chung HY, Lee EK, Choi YJ, Kim JM, Kim DH, Zou Y, et al.. Molecular inflammation as an underlying mechanism of the aging process and age-related diseases. J Dent Res 2011;90:830-840.

19. Iglhaut G, Schwarz F, Winter RR, Mihatovic I Stimmelmayr M, Schliephake H. Epithelial attachment and downgrowth on dental implant abutments. J Esthet Restor Dent 2014;26:324-31.

20. Blaser H, Dostert C, Mak TW, Brener D. TNF and ROS crosstalk in inflammation. Trends Cell Biol 2016;26:249-261.

21. Morgan MJ, Liu ZG. Crosstalk of reactive oxygen species and NF-kappa B signaling. Cell Res 2011;21:103-115.

22. Gutiérrez-Venegas G, Kawasaki-Cárdenas P, Arroyo-Cruz SR, MaldonadoFrías S. Luteolin inhibits lipopolysaccharide actions on human gingival fibroblasts. Eur J Pharmacol 2006;541:95-105.

23. Silva TA, Garlet GP, Fukada SY, Silva JS, Cunha FO. Chemokines in oral inflammatory disease: apical periodontitis and periodontal disease. J Dent Res 2007;86:306-319.

24. Terheyden $H$, Stadlinger B, Snaz M, Garbe Al, Meyle J. Inflammatory reaction - communication of cells. Clin Oral Implants Res 2013;25:399407.

25. Benatti BB, Silvério KG, Casati MZ, Sallum EA, Nociti FH Jr. Inflammatory and bone-related genes are modulated by aging in human periodontal ligament cells. Cytokine 2009;46:176-181.

Received February 25, 2016 Accepted July 27, 2016 